\title{
How the dark horse came in \\ Portland State University Library acquires Dark Horse Comics archives
}

t's another hot night, dry and windless. The

kind that makes people do sweaty, secret things. I wait and listen. For a while it's quiet as it gets in Sin City."

In 2008, the Portland State University Library acquired the archives from the third largest comics publisher in the United States, the Milwaukie, Oregon-based Dark Horse Comics, Inc. Portland State University alumnus Mike Richardson, founder and president of Dark Horse Comics, Inc., and Neil Hankerson, executive vice president, donated multiple copies of all publications and products generated by Dark Horse from its establishment in 1986 to the present and will continue to provide copies of all future items produced by the company. ${ }^{2}$ Richardson's hour-long presentation covers the history of comics from format changes to the Comics Code to the advent of art comics and the graphic novel. ${ }^{3}$

This generous gift will re-

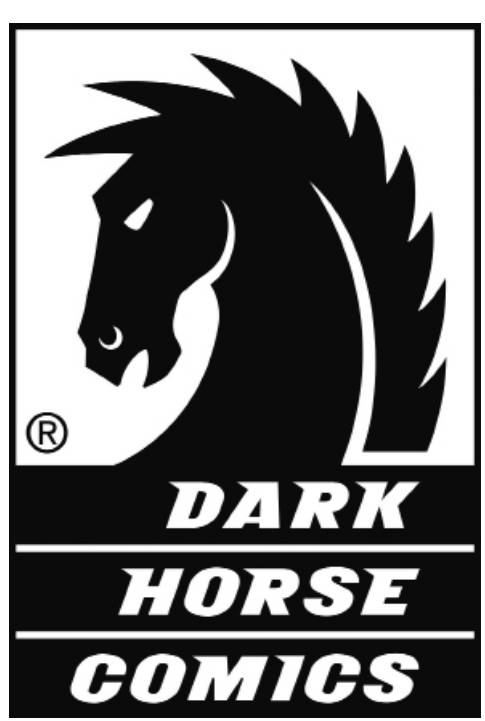

Dark Horse Comics ${ }^{\circledR}$ and the Dark Horse logo are trademarks of Dark Horse Comics, Inc., registered in various categories and countries. All rights reserved. the general Portland State Library collection, is available to more than 26,000 students at Portland State University as well as more than 200,000 students and faculty in Oregon and Washington through the Orbis Cascade Alliance academic library consortium. National and international access via the Portland State Library's interlibrary loan service also is available to interested readers.

University Librarian Helen H. Spalding states, "This collection will be a destination resource for researchers in popular culture, gender studies, communications, and sequential art. Even the business and publishing programs will have products, packaging, and advertising materials to study." 4

To date, more than 2,000 Dark Horse comics, graphic novels, manga and books have been received, cataloged, and made available for students and faculty to check out at the Portland State Library. Access points in the bibliographic result in a complete collection of the Dark Horse corpus to be preserved in the Portland State University Library Special Collections. The research collection contains one copy of every Dark Horse comics book, graphic novel, collected edition, foreign translations of Dark Horse original works, book, print, poster, statue, figure, and all other products. An additional circulating library of the published Dark Horse canon, added to cords are provided for not only authors and illustrators, but other important contributors, including colorists and engravers, opening

Michael Bowman is comics librarian, e-mail: bowman@ pdx.edu, Cristine N. Paschild is special collections librarian, e-mail: paschild@pdx.edu, and Kimberly Willson-St. Clair is public relations coordinator, e-mail: willsons@pdx.edu, and at Portland State University

๑ 2009 Michael Bowman, Cristine N. Paschild, Kimberly Willson-St. Clair 
avenues of research about these important artists and their work. ${ }^{5}$ The 20 languages represented in the collection provide additional material for students in Portland State's foreign language program.

Making a lasting impact on the industry, Richardson sought to establish an ideal atmosphere for creative professionals and set a policy that Dark Horse offer creators ownership of their works, at a time when other publishers were reluctant to acknowledge artists' copyrights. Dark Horse began with two titles, Dark Horse Presents, an anthology series, and Boris the Bear. The success of these titles enabled Dark Horse to expand its publishing line. In the company's second year, it began publishing manga, making Dark Horse Comics one of the earliest translators of manga in the United States. Today the company releases approximately 30 comic books and graphic novels per month. Dark Horse comics and creators have received 94 Will Eisner Comic Industry Awards, the comics industry's most respected award.

Notable series include Mike Mignola's Hellboy and Frank Miller's Sin City. Mignola's series about the mythic character, Hellboy, combine themes from folktales, epics, and fairy tales to spin adventure stories set in the latter half of the 20th century. Mignola opens The Right Hand of Doom by reciting Edgar Allan Poe's "Lygeia" juxtaposed with panels depicting dusk at an eerie castle where vampires await their awakening. In Sin City, Frank Miller, also noted for revitalizing Batman in The Dark Knight Returns series, creates a contemporary, hard-boiled detective narrative that echoes classics by Raymond Chandler and John M. Cain. Depicted in stark black- and-white images, Sin City features Dwight, a scruffy ver- sion of Philip Marlowe, and a Frankenstein's monster-like character named Marv. Star Wars, the Alien series, and Buffy the Vampire Slayer are original interpretations of the films and TV series. These syndication narratives have been written about as part of popular 20th-century American culture, including a Buffy lexicon published Oxford University Press, Michael Adam's Slayer Slang: A Buffy the Vampire Slayer Lexicon, and a critical deconstruction of the Buffy saga, Rhonda Wilcox's Why Buffy Matters: The Art of Buffy the Vampire Slayer. ${ }^{6}$

At Portland State University, Diana Schutz, Dark Horse executive editor and multiple Eisner award recipient, teaches two courses, "Contemporary Comics Theory" and "Understanding Comics Art," which focus on sequential art work from Winsor McCay to Alan Moore to Frank Miller. Schutz commented,

Portland State University is one of the current crop of forwardthinking universities that are supporting the exciting new discipline of Comics Studies, not only with the incredible backing of the Portland State Library for acquisitions of this sort, but also by offering comicsrelated courses via their English and Art departments. It's been a pleasure to be part of this new academic sphere and to introduce students to some of the real classics of the medium. ${ }^{7}$

The collection also holds great potential for researchers. According to chair of the Sequential Art Department at the Savannah College of Art and Design David Duncan:

A complete and continuing collection such as this is surely a great benefit 
to scholars and historians. The most heartfelt beneficiary will be the young cartoonists who will find true inspiration in their first exposure to the artists and stories in the books. This collection represents an impressive cross-section of genres, styles, and readerships; the demographic of those that can be positively affected by this acquisition is just as diverse. I hope that this will be an inspiration to other publishers and academic libraries that will follow Dark Horse and Portland State University Library's lead in nurturing future comic creators and scholars. ${ }^{8}$

With the vast Dark Horse collection meticulously cataloged for scholarly research, more courses on campus will incorporate these visual/ verbal narratives into the classroom.

Anchored by the Dark Horse Comics archives, and ideally situated in the heart of a city known for its thriving comics creators' community,

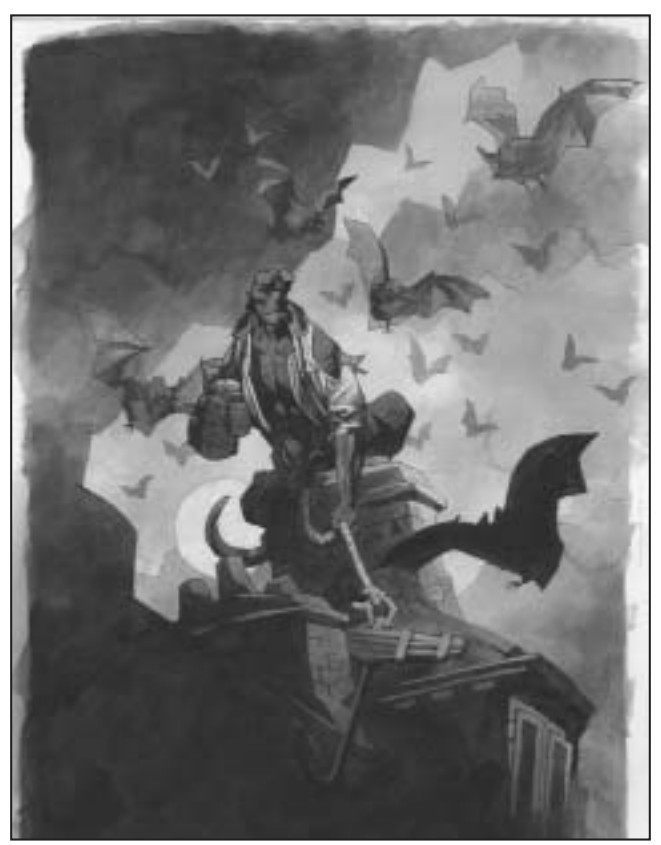

Mike Mignola's Hellboy ${ }^{\mathrm{TM}}$ (c) 2009 Michael Mignola. All rights reserved. the independent publishing and promotion industry.

\section{Notes}

1. Frank Miller, Sin City: The Frank Miller Library Set I, Volume II: A Dame to Kill For (Milwaukie, OR: Dark Horse Books, 2005), 1.

2. Portland State University Library, October 31, 2008, "Video from Dark Horse Comics Celebration," www.media.pdx.edu/Library /Dark_Horse_Event_101608.asx (accessed October 14, 2009).

3. Douglas Wolk, Reading Comics: How Graphic Novels Work and What They Mean (Philadelphia: Da Capo Press, 2007). Read Wolk's Reading Comics for a comprehensive, critical exploration of art comics and graphic novels.

4. Helen H. Spalding, university librarian, Portland State University Library, e-mail to Kimberly Willson-St. Clair, July 3, 2009.

5. Gary Markham, "Cataloging the Publications of Dark Horse Comics: One Publisher in an Academic Catalog," Journal of Academic Librarianship 35, no. 2 (2009): 162-69.

6. Michael Adams, Slayer Slang: A Buffy the Vampire Slayer Lexicon, (New York: Oxford University Press, 2003). Rhonda Wilcox, Why Buffy Matters: the art of Buffy the vampire slayer (London: I.B. Tauris, 2005).

7. Diana Schutz, Dark Horse Comics executive editor, e-mail to Kimberly Willson-St. Clair, July 1, 2009.

8. David Duncan, Sequential Art Department chair, Savannah College of Art and Design, e-mail to Kimberly Willson-St. Clair, July 2, 2009. 